\title{
REFUGEES CHILDREN AND YOUTH SOCIAL SKILLS EDUCATION IN FOOTBALL ACTIVITIES
}

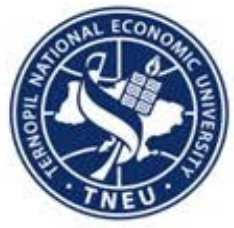

Mykhailo Kotsiubynskyi State Pedagogical University, Ukraine E-mail: innaasauliuk@gmail.com

\section{Alma Paskevice \\ Lithuanian Sports University, Lithuania}

E-mail: alma.paskevice@stud.lsu.lt

Jurate Pozeriene

Lithuanian Sport University, Lithuania

E-mail: jurate.pozeriene@lsu.lt

Olena Dyka

Zhytomyr Polytechnic State University, Ukraine

E-mail:dyolena@ukr.net

Inna Asauliuk

Dana Olefir

Vinnytsia Mykhailo Kotsiubynskyi State Pedagogical University, Ukraine E-mail: dayanaolefir1675@gmail.com

Submission: 8/25/2021

Accept: 9/26/2021

IJTM\&:

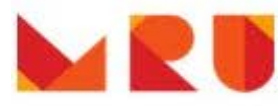

MYKOLAS ROMERIS UNIVERSITY

\section{ABSTRACT}

The number of sports programs in the world to promote various integration processes is growing rapidly. Physical activity and sport, and football in particular, are an excellent strategy for dealing with the various resettlement challenges of refugee children and youth (Stura, 2019; Anderson et al., 2019; Robinson et al., 2019; Svensson \& Woods, 2017; UN Refugee Agency, 2019). Scientific problem question: how are the social skills of refugee children and youth developed in a group of football activities? Aim: to analyze the concept of social skills development in a group of football activities for refugee children and youth and to identify problems of social skills development. Objectives of the research: To highlight the peculiarities of physical activity of refugee children. To reveal the role of social skills in the development of social skills of refugee children through physical activity in the integration process. To analyze the results of the practical evaluation of the football program "Football3” developed 
INDEPENDENT JOURNAL OF MANAGEMENT \& PRODUCTION (IJM\&P)

http://www.ijmp.jor.br

v. 12, n. 6, Special Edition ISE, S\&P - November 2021

ISSN: 2236-269X

DOI: $10.14807 /$ ijmp.v12i6.1780

by the international network "STREET FOOTBALL WORD”. The result: Football has always been closely linked to the phenomenon of forced migration worldwide. Football or physical activity has the incredible power to help shape the future and give hope to refugee children and youth living in other countries. The study revealed that the development of a football program and the productivity of practical efficiency were determined by the service provider's experience in volunteering abroad as a football coach using the Football3 method. According to informants, the stability of the structure of the football program emerged after the third season.

Keywords: football; refugee children and youth; social skills; education

\section{INTRODUCTION}

Relevance of the research. At the beginning of the 21st century, migration processes became globalized. In 2019, nearly 26 million refugees around the world were forced to flee abruptly from their home country. Perhaps the most vulnerable group of refugees are children and youth, who account for the largest percentage of forced migrations (U.N. High Commissioner for Refugees, 2019). This group of forced migrants faces major integration challenges in foreign countries, such as forced learning of a new language, cultural shock (Shakya et al., 2010), establishing social contacts with peers and adults, which may threaten their well-being (Paškevičè \& Požėrienè, 2020).

The access of education had a significant positive effect on consumer empowerment. In contrast, the lifestyle did not have a significant and positive impact on consumer empowerment (Simanjuntak, \& Mubarokah, 2020). Therefore, researchers and sports expertscoaches need to find new strategies and solutions that will help reduce the problems of their integration into society.

In accordance with Council of the European Union January 27 Directive 2003/9 / EC recognizes refugees who have survived military conflicts, poverty, violence, natural disasters and repression as the most vulnerable group of migrants experiencing social exclusion. Refugees are trying to find safe refuge in refugee camps in neighboring countries before moving to third countries. The countries of the European Union, including Lithuania, which have received asylum seekers, have committed themselves to receiving refugees and integrating them into the society of their country. Refugee mobility is most affected by forced migration because of their vulnerability (Bartlett, et al., 2017; Žibas, 2017). 
Scientific problem question: how are the social skills of refugee children and youth developed in a group of football activities? Problematic questions inspiring the research: What sport determines the successful integration of refugee children into society? Can football programs become an exceptional tool for integration if they do not aim for a sporting outcome but aim for a productive change in the life of a child or young person by developing social skills during football training?

1.1. The relevance of the scientific problem of the research is substantiated by the following circumstances:

a) There are insufficient and very few researches in Lithuania to study the issue of physical activity of refugee children (there was only an EU project in Rukla and no more information about research related to physical activity was found)

b) There are few sports programs to help refugee children integrate into society (Vilnius social club-a non-governmental organization that works not only with Lithuanian children, but also with refugee children, football - without a sports result)

c) There is a lack of research on the integration needs of refugee children and young people and the impact of their sport on solving the problems of this population.

d) Sport can reduce traumatic stress, promote mental well-being, develop social skills and promote social integration and general physical health.

The object of the research is the development of social skills in football classes

Aim: to analyze the concept of social skills development in a group of football activities for refugee children and youth and to identify problems of social skills development.

\subsection{Research tasks:}

a) To highlight the peculiarities of physical activity of refugee children.

b) To find out the development of social skills of refugee children through physical activity in the integration process.

c) To analyze the results of the practical evaluation of the football program "Football3" developed by the international network "STREET FOOTBALL WORD” 
DOI: $10.14807 /$ ijmp.v12i6.1780

The research is based on the following theoretical provisions: Social - cognitive learning theory (Albert Bandura); Psychosocial Theory of Personality Development (E.Erikson)

\subsection{Research methods:}

a) Analysis and meta-analysis of scientific literature, allowing to contextualize the concept of refugee children and youth in theoretical discourses, substantiation and features and peculiarities of the theoretical concept of physical activity. Traits, opportunities and positive socialization of social skills development of refugee children and youth, development of social skills through physical activity. The essence of football as a physical activity in educating refugee children and youth.

b) Qualitative research Interviews with experts.

\section{LITERATURE REVIEW}

\subsection{Substantiation of the theoretical concept of physical activity of refugee children and youth}

To reveal the concept of a refugee would be significant in our own understanding of who a person is, because one of the conditions of human rights is his presence on earth. So in Scripture the question is who is man? is described in the Psalm of David in the eighth chapter, which mentions the dignity and greatness bestowed on man (Scripture, 2009).

This question was raised, among other philosophers, by one of our most famous philosophers, Immanuel Kant. He believed that the whole philosophy was based solely on this question, and he argued that man is an intelligent being, with the autonomy of the practical mind, where the mind gives man exceptional status and is the probability of his autonomy.

Kant is not the first thinker to ask the question, who is man? (Kant, 1980). Continuing on the philosophical path, the concept of man was explored in Christian anthropology, which was associated with Thomas Aquinas 'insights about man. He emphasizes that man is from the soul and the body - in one. Tomas Aquinas sought to combine theology and philosophy, using the principles of Aristotle's philosophy that man is a living being with a reasonable soul and able to participate in social and political life (Stančienè, 2002; Laumenskaitè, 2014).

Revealing the philosophical concept of man, attention is paid to the process of forced migration mobility. The term migration (lat. Migration) is defined when people or a group of 
INDEPENDENT JOURNAL OF MANAGEMENT \& PRODUCTION (IJM\&P)

http://www.ijmp.jor.br

v. 12, n. 6, Special Edition ISE, S\&P - November 2021

ISSN: 2236-269X

DOI: $10.14807 /$ ijmp.v12i6.1780

people move from one place to another. International migration has become a clear trend in the globalized world in the 21st century and is described differently by many researchers and academics (Jasiulevičienè, 2008; Butkus et al., 2010; Skirbutaitė, 2010; Leveckytė et al., 2014; International organization for migration, 2019).

The existence of the migration process in the world is as old as humanity itself. The mobility of people around the world influences the search not only for better living conditions, but also to escape military conflicts, natural disasters, persecution in the home country (Castelli, 2018).

In summary, we can say that man is a living, autonomous, intelligent, thinking being. Which may be young or old, woman, man or child, hardworking or lazy, white or black, religious or non-religious, educated or not, but he is still human. Various efforts to empower and protect consumers have been made by the government and various non-governmental consumer protection organizations (Simanjuntak \& Umiyati, 2020). So, a refugee is also a human being and is no different from us, only in that he cannot live freely in his homeland, due to military conflicts and so on. unrest and we can live safely. The concept of refugee is linked to legal debates and is recognized under the 1951 Act. Geneva Convention. The refugee is also distinguished by the fact that his / her migratory mobility is sudden, flies unplanned from his / her home country, and becomes vulnerable. It is observed that the active mobility of refugees consists of children and young people under 18 years of age. population. This population is particularly vulnerable, fragile and causes painful moments as a disruption of formal or non-formal education.

As stated by Vveinhardt and Ganusauskaitè (2021), quoting (Arafat et al., 2016) Cross-cultural adaptation requires to use a unique method so that the original and adapted versions of the questionnaire are equivalent. Sport, a physical activity in the 21st century, has a holistically positive effect on the human body and is one of the priorities of the modern education system (Czosnek et al., 2019).

Efforts are being made around the world to use sport or physical activity as a key factor in integrating the lives of children and young people, as there is a lack of widespread physical literacy. Refugee children and youth face a wide range of challenges such as poverty, war, forced sudden migratory mobility (Coakley, 2011).

Any physical activity helps to solve difficulties, not only in integration into society, but also in everyday activities, how to learn to communicate, insight into positivism, in any 
DOI: 10.14807/ijmp.v12i6.1780

activity, formation of appropriate values, to the view that spending leisure time is physically active, will be meaningful and useful. for general health (Šidlauskienè et al., 2019).

With the increase of mental stress in competitions and the growth of general level of athlete technical and tactical preparedness and physical condition, psychological aspects are more and more emphasized in winning a game in team sports (Vazne et al., 2018).

The concept of professional competencies is defined in many ways. In the area of physical culture (physical activity as a sphere of practice and sports science as research exploration), this concept is understood in two ways, both as a range of rights to perform certain roles, certified by a document authorizing to deal with a given specialty, and as a range of specific knowledge, skills and attitudes, thanks to which the individual effectively achieves the assumed goals with the help of educational interactions (Litwiniuk, Waldzinski \& Grants, 2020).

\subsection{Social skills development opportunities and positive socialization of refugee children and youth}

Literature reviews are assumed that during physical activity occurs positive emotional changes. However, statistics on population physical activity habits indicate that only a small proportion of society engage in physical activity (Ulme et al., 2017).

The socialization of refugee children and youth in host countries poses many challenges, not only for child development but also for psychological and social adjustment of members of the host community (Busch et al., 2019).

Socialization examines the relationship between the individual and society, it is clear that theory is closely related to sociology, psychology, social pedagogy (Kvieskiené, 2003).

The beginning of a child's or young person's socialization begins with copying, imitating the behavior of the surrounding people (Giedrienè, 2015).

Zaleckienè (2004) points out that socialization takes place not only by imitating, taking over what has already been created, and thus trying to adapt to society, but also by consciously trying to remain independent. Socialization will only be successful if man himself becomes what he really is.

Good development of socialization instruments is essential to facilitate the integration of refugee children and young people. The main instruments of socialization (presented in 
INDEPENDENT JOURNAL OF MANAGEMENT \& PRODUCTION (IJM\&P)

http://www.ijmp.jor.br

v. 12, n. 6, Special Edition ISE, S\&P - November 2021

ISSN: 2236-269X

DOI: $10.14807 /$ ijmp.v12i6.1780

Figure 1) are important for their productive integration into host communities and societies (Giedrienè, 2015).

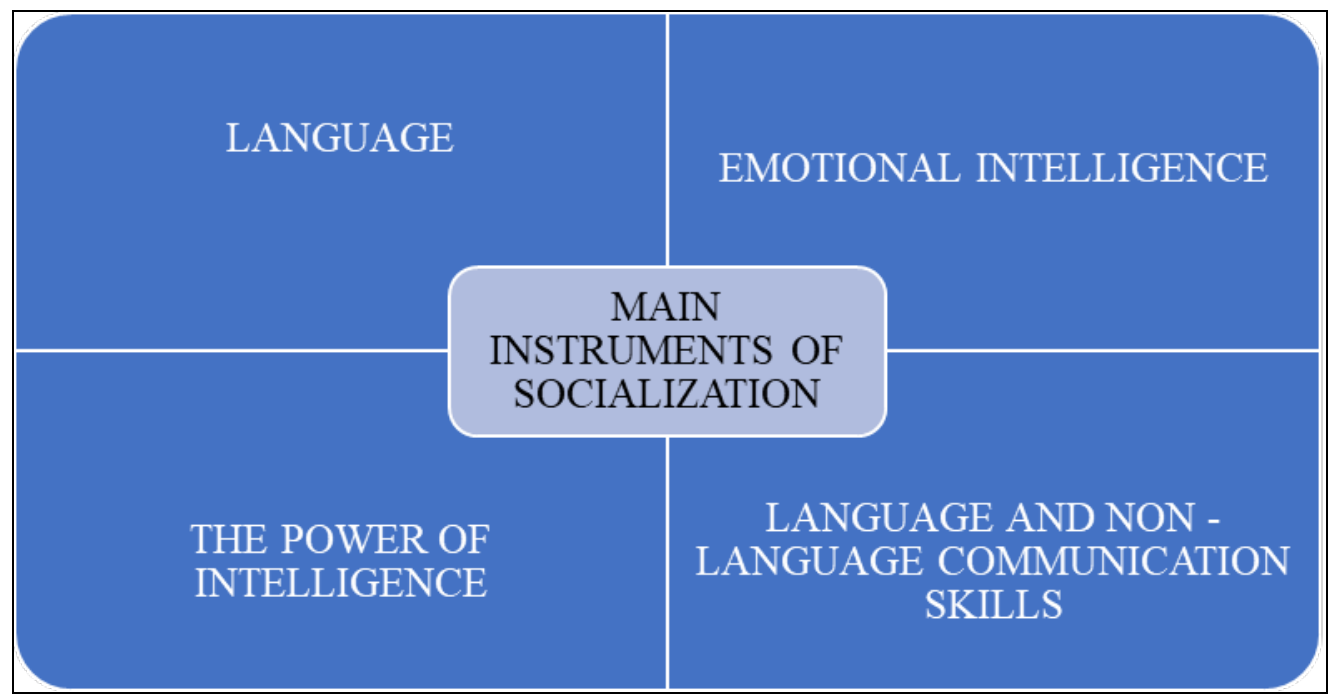

Figure 1: The main instruments of socialization

Source: compiled by the authors of the work, based on Giedriene (2015)

From Figure 1 it can be seen that the instrument of socialization covers four aspects, namely language, emotional intelligence, intellectual power, and linguistic and non-linguistic communication skills.

In order to improve the socialization of children and youth, one of the most significant activities is physical activity. We can say that physical activity is a great school of life, where one learns the characteristics of physical activity, such as adherence to discipline, personal growth, safe and cozy environment, functioning in a different team of members, reconciling with winning or losing (Havighurst et al., 2015; Daniulienè \& Dadelienè, 2020; Raffier, 2020).

The actions of positive diplomacy are reflected in socialization. Thus, this phenomenon is related to positive things, such as widespread access to education for children and youth, opportunities for governmental and non-governmental institutions to influence the positive socialization of children and youth, spread antisocial behavior prevention, develop multicultural expression (Kvieskienè, 2003).

In childhood, the most intense process of socialization begins, when a child learns and takes over from an adult the most important social skills, language, behaviors, communication or daily activities (Vaitkevičius, 1995).

The process of socialization determines the socialization of each person, which is affected by another individual or even groups. The most important process of socialization 
INDEPENDENT JOURNAL OF MANAGEMENT \& PRODUCTION (IJM\&P)

http://www.ijmp.jor.br

v. 12, n. 6, Special Edition ISE, S\&P - November 2021

ISSN: 2236-269X

DOI: $10.14807 /$ ijmp.v12i6.1780

takes place in the family, but let us not forget that educational institutions, religion, society or the leisure time allowed in certain organizations also have an influence.

Certain features of socialization are very important for the integration of refugee children and youth into society, which have a positive effect during integration (Kvieskienè, 2003).

During the socialization process, refugee children and young people become acquainted with the customs of the host community and society in order to live productively. The features of socialization vary depending on the country's culture, family, child, and situation (Bugental, 2000). The features of socialization are presented in Figure 2.

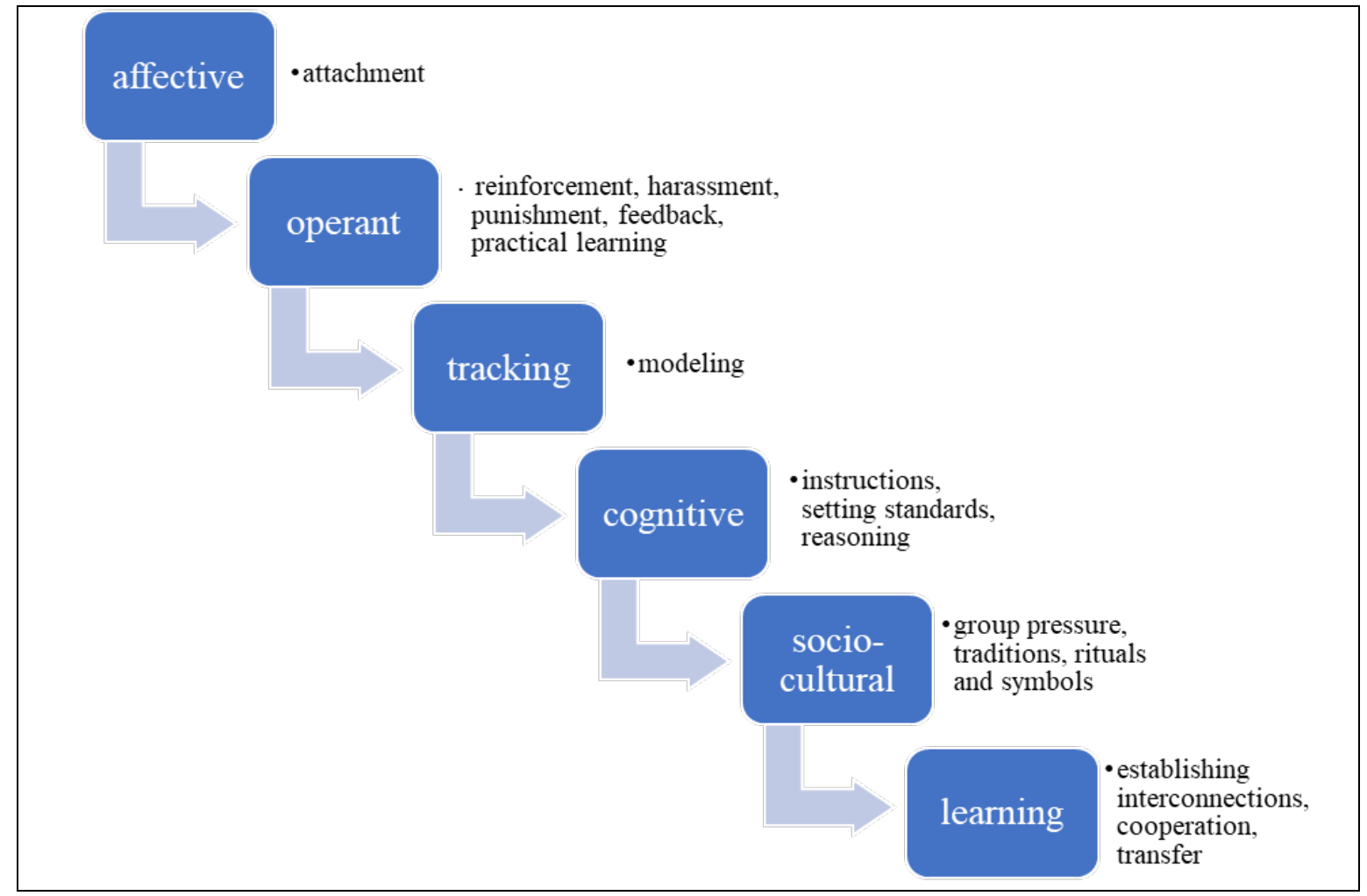

Figure 2: Features of socialization

Source: Compiled by the authors of the work, based on Bugental (2000) and Berns (2015)

Figure 2 presents six features of socialization that help an individual to productively socialize into the community.

An emotional trait is equivalent to emotional literacy, which is related to feelings and emotions. The central accent of this trait is improvement, not only among oneself, but also among the individuals of society. Human socialization occurs through interpersonal interactions, as the feeling arises from maintaining productive interpersonal relationships (Berns, 2015). Collins et al. (2000) argue that the onset of an individual's socialization comes from a person's attachment. When a child has a productive emotional connection with an 
adult, then other abilities appear in socialization under the influence of operant, observational, cognitive, socio-cultural and learning traits.

An operant trait that influences when the environment changes the form of a response (Souza-Barba, 2012). This trait takes into account the role of the person himself in his socialization, as the existing behavior is followed by the expected reward and thus it is believed that such behavior will be repeated. However, it is also the case that the behavior may not bring the expected reward or the expected result is negative and then the probability of such behavior recurring decreases (Berns, 2015).

The feature of tracking or modeling is a very important feature of socialization. It is exemplary learning by imitating the behavior of another individual and experiencing the consequences of that behavior. This trait indirectly helps to learn the appropriate social behavior, attitudes, emotions, values for the individual.

Bandura (2001) argues that an individual's use of the observational trait in socialization will depend on attention, level of cognitive development, memorization, type of activity observed, motivation, ability to reproduce behavior, and available alternative behaviors.

The cognitive effect of a trait in the productive socialization process arises from information processing. Individuals use certain strategies in the process of socialization: instructions, setting standards, and reasoning that help them socialize more productively in society (Berns, 2015).

Socio-cultural traits are also crucial to socialization traits. This trait is learned from the newborn and the individual learns to behave properly in his social environment, acquires knowledge, becomes acquainted with art, has certain beliefs, follows orders, customs and traditions (Berns, 2015).

The learning feature begins with the coach structuring the session according to the child's abilities, and then cooperating in the session and providing productive support when needed, and then gaining more skills, then shifting responsibility for the outcome of the session (Berns, 2015).

\subsection{3. Development of social skills through physical activity}

In a rapidly changing world, the usefulness of developing a variety of social skills in the context of physical activity for both children and young people is taken into account 
INDEPENDENT JOURNAL OF MANAGEMENT \& PRODUCTION (IJM\&P)

http://www.ijmp.jor.br

v. 12, n. 6, Special Edition ISE, S\&P - November 2021

ISSN: 2236-269X

DOI: $10.14807 /$ ijmp.v12i6.1780

(Opstoel et al., 2020). Wright, Craig (2011) argue that developing social skills will make it easier for children or youth to transition into adult life. Research shows that children or young people can develop social skills through regular physical activity. Physical activity can promote positive youth development through the acquisition of life skills, psychosocial, and behavioral traits that pass through an individual’s lifetime (Weiss, 2011).

Given the nature of physical activity or sport, it is considered an appropriate educational tool for developing children or young people not only personal but also social skills (Opstoel et al., 2020).

Children and young people are not only the present but also the future of us all, so their education begins with the challenges of social life. Every child or young person in the development of their social process, in which they cultivate the general social values of society. They learn to adapt to changing group norms, morals, or cultural traditions (Mayar, 2013; Dewi et al., 2020; Ali et al., 2021).

Deficiencies in social skills manifest themselves in the development of emotional and behavioral disorders in both children and young people. The aim is to increase the ability to perform basic social behaviors through social skills training, which is important for productive success in host communities. Social skills training is recognized in many approaches to the treatment of many emotional, behavioral, and developmental disorders (Spence, 2003).

According to Gillham, Shatte and Freres (2000), social skills are one of the key factors that help to adapt productively in any environment. However, a different description of social skills is accepted, such as the ability to recognize one's individual needs, pursue more productive social interactions, communicate appropriately, and resolve conflicts constructively (Anderson-Butcher, et al., 2020), and the ability to translate reflection on one's behavior (Raffier, 2020). Wright, Gordon and Gray, (2020) argue that social skills learning competencies, such as self-awareness, relationship skills, and responsible decision-making, are productively integrated during physical activity.

Orr et al., (2021) argue that children and youth with social skills disorders face challenges that hinder participation in their community in the process of physical literacy, so the study found that incorporating physical literacy into daily community activities has positive social skills development. 
The development of social skills curricula for children and young people has a positive effect on educational social skills, how to transfer knowledge, self-confidence and others through physical exercises, improve interpersonal skills, distinguish not only good but also bad emotions (de Mooij et al., 2020).

The benefits of sports and active recreation programs provide an opportunity for each child or young person to strengthen physically, improve psychological well-being, and with the help of sports develop social skills, and stronger, more sustainable social relationships have been observed (Sibson et al., 2020).

In summary, the development of social skills and physical activity forms an autonomous personality by improving an individual's participation in society or a smaller community. Also, social skills are a fairly important part of an individual's construct that embraces the individual holistically in his or her social life.

\subsection{Football as a physical activity in the education of refugee children and youth}

Football has evolved from a simple kicking of the ball without any rules to a modern football sport with rules and matches. Football is said to be a highly emotional and challenging sporting activity or leisure activity (Joo et al., 2016).

Many would say that basketball has a unique power to change the lives of children and youth (Harwood et al., 2021), but football also has a rather strong unique power to change the lives of refugee children and youth in foreign countries in an attempt to integrate into their communities. A sport like football is used as a social tool, but in the absence of a sporting outcome, there is little information on the effectiveness of scientific substantiation in doing so.

The role of football in the lives of refugee children and youth is examined as the role of community sports in the social process (Stone, 2018). Football has a positive effect on an individual's attitude not only to life, but also to a peaceful approach to resolving emerging conflicts.

Football is a sport that also ensures a healthy lifestyle for children and young people (Michelini, 2021) and high self-esteem. Football camps are used in the Syrian refugee camp in Jordan to improve the emotional development of refugee children and youth. It is said that the game of football will help to recover from the traumatic shock. 
Although leaders of Islamic religions condemn sport, football activities are a great help in integrating children and youth of that nationality into communities (Maharmeh, 2013; Pastoor, 2017; Im et al., 2020).

According to Tuastad (2014), football is a key tool that allows children and young people to feel like autonomous individuals. Sports activities for refugee children and youth are a productive opportunity to integrate not only with each other but also with host communities.

However, it has been observed that productive integration depends on active coaches, a safe and comfortable environment and that sporting activities are not linked to sporting outcomes but aim for productive change in a child's or young person's life through social interaction (Doidge et al., 2020; Raffier, 2020).

A wide range of child- and youth-focused sports programs have gained a successful process of physical activity over the past two decades, using sport as a tool to address complex integration and social issues (Coakley, 2011; Kay, 2012; Coalter, 2015; Cunningham et al., 2020).

Football activities are organized not only to create social peace, but also for children and youth to successfully integrate and return to school (Gadais et al., 2021).

The children in the study reported that when they participated in football activities, they noticed some positive changes in their lives, such as increased self-esteem, positive changes in behavior, perceptions, and relationships with members of the host community (Thomas, 2020).

\subsection{Football3 developed by STREET FOOTBALL WORD}

The international network STREET FOOTBALL WORD was established in 2002. with the goal that one of the sports, football, can be a productive tool in every changing society in the world facing a wide range of challenges, such as the productive integration of refugee children and young people into host societies. In this organization, the game of football is used as a universal nonverbal physical language to unite the global community in overcoming the greatest modern challenges posed mainly by the phenomenon of forced migration. Also developed a tool / method for Football3.

The aim of this measure / method is a productive change in the life of a child or young person and no sporting results are sought, but the priority is a qualitative change in the life of 
INDEPENDENT JOURNAL OF MANAGEMENT \& PRODUCTION (IJM\&P)

http://www.ijmp.jor.br

v. 12, n. 6, Special Edition ISE, S\&P - November 2021

ISSN: 2236-269X

DOI: $10.14807 /$ ijmp.v12i6.1780

each child or young person. Using this method, it has been observed that socio - educational changes affect communities differently in integrating refugee children and youth. It has become clear that football as a sport is a universal sports tool that changes the lives of refugee children and young people.

The game of football gives refugee children and young people more self-confidence, develops and acquires new social skills, integrates more easily into host communities, schools, removes the barrier of bilingualism, the opportunity to communicate with peers and share reflection. This organization seeks to ensure that governmental or non-governmental organizations around the world use the football game not only as a non-sporting sporting outcome, but also as a socio-educational support for children and young people (Street football word, 2021; Raffier, 2020).

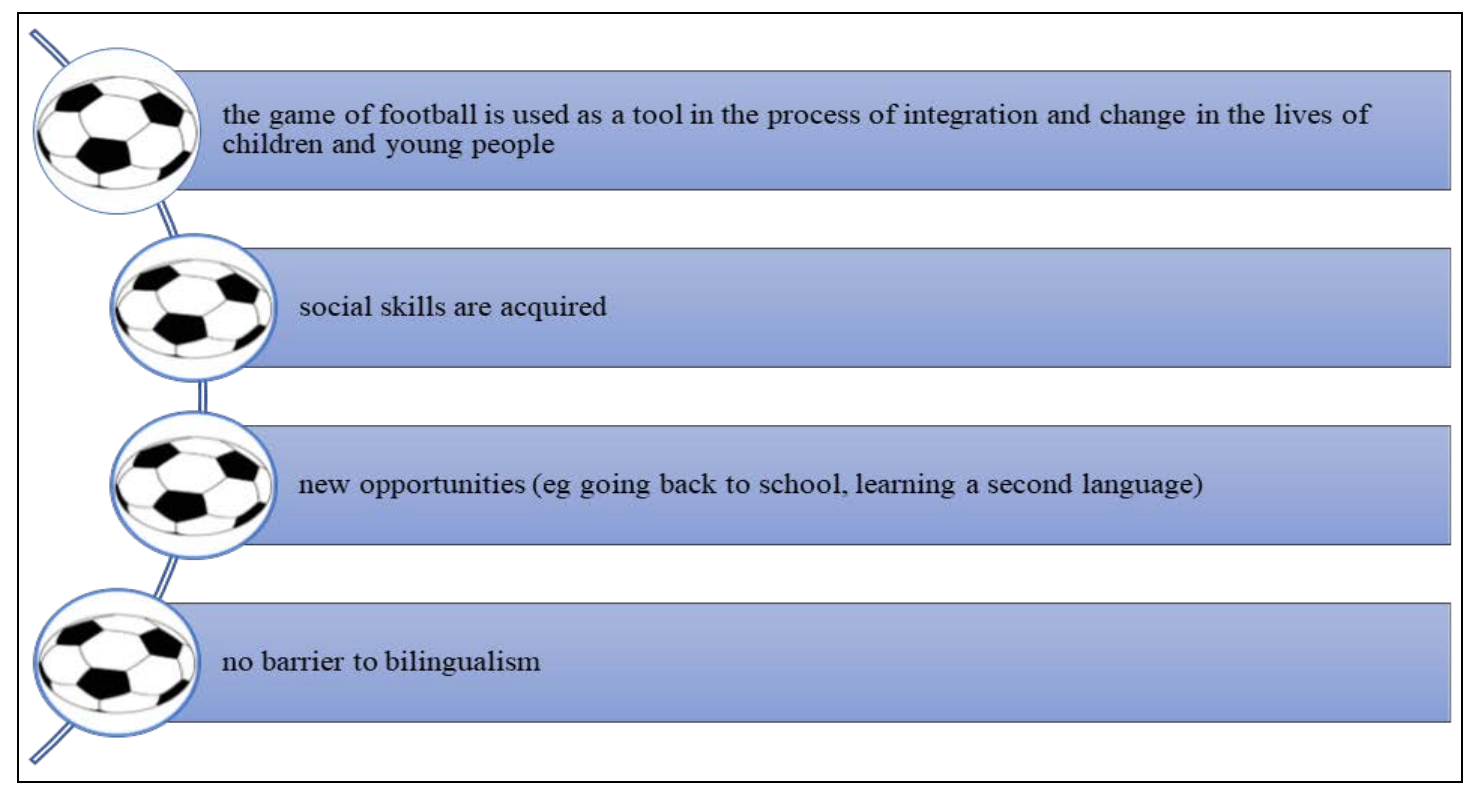

Figure 3: The benefits of football in the lives of children and young people Source: Compiled by the author based on Street football word (2021) and Raffier (2020)

From Figure 3. it can be seen that football activities have productive implications in the lives of a child and a young person. The game of football is used as a productive tool for successful integration into host communities and in the process of change in the lives of refugee children and youth. It is considered to be one of the most productive means of integration and change through sport - football (Ekholm, 2019).

Flensner et al. (2020), state that sport is considered an important factor in promoting integration, which is reflected even in international policy documents. A study by Flensner et al., (2020) focused on how non-governmental organizations in the host community, which 
INDEPENDENT JOURNAL OF MANAGEMENT \& PRODUCTION (IJM\&P)

http://www.ijmp.jor.br

v. 12, n. 6, Special Edition ISE, S\&P - November 2021

ISSN: 2236-269X

DOI: $10.14807 /$ ijmp.v12i6.1780

consisted mainly of forced migrants, volunteer as football coaches to work to promote integration through football.

There were regular training sessions and matches with teams of children, youth and adults. The study found that the work of football coaches from a sports club NGO in terms of integration was linked to the fight against segregation, rules and the language barrier. Both football coaches and respondents emphasized that sporting activities strengthened feelings of trust despite segregation in society, and volunteer football coaches worked to build good relationships and make sporting activities a safe environment for forced migrants visiting the organization, not only adults but also children and young people.

Language is one of the key factors in the integration process. Language skills in host communities can provide refugee children and young people with better communication skills that can be useful for education and a more active life in society. It is very important for refugee children and young people to learn the language of the host country in which they live. Knowledge of a second language and literacy is very important, as it affects the successful further integration of a refugee child and young person.

Researchers in research with children and youth of Syrian refugees have found that proficiency in English is important in helping them adapt to the existing environment. The main environmental factor was the subjects 'homes, which used both their mother tongue and a second foreign language among their parents, siblings. The results of the study showed that the use of both the mother tongue and the second foreign (English) language in the home environment has become richer not only for the development of word but also for literacy learning (Paradis et al., 2020).

Through a variety of sports activities such as football training, we can develop social skills that are very important to an individual in their personal lives. These skills are most important for refugee children and young people, such as problem-solving, productive communication and collaboration skills with adults, developing responsibility, building good relationships and making independent decisions. They can acquire these skills through life experiences, as well as through continuous improvement through learning and physical activity. Good social skills can help refugee children and youth to easily integrate into society and become active citizens of the host society (Nassou et al., 2020) 
In summary, football has always been closely linked to the phenomenon of forced migration on a global scale. Football or physical activity has the incredible power to help shape the future and give hope to refugee children and youth living in other countries.

\section{DATA AND METHODOLOGY}

\subsection{Research methodology}

In order to highlight the education of refugee children and youth through physical activity in Lithuania, a qualitative study - an interview - was chosen to implement the study. Luobikiene (2010) states that qualitative research is based on strict methodological traditions. However and Kardelis (2016) and Tidikis (2003) state that with the help of qualitative research we can get deeper, more productive and wider information from informants and describe it later. Study Date: Two football coaching experts were interviewed (October 2020).

Semi-structured interview: In education, one of the main methods of collecting data from qualitative research is the interview. Interviewing is one of the methods of qualitative research that is most commonly used to obtain information from a person, group, or organization (Kardelis, 2016; Alvesson, 2011). Kardelis (2016) and Rupšienè (2007) state that the interviewed experience of the informant is productively perceived during the interviews.

According to Rupšienė (2007), a semi-structured interview also has advantages when the obtained data are comprehensive and systematized, despite the fact that the interview was conducted in an informal way.

Tidikis (2003) also describes the most important possible elements in a semistructured interview.

Žydžiūnaitė and Sabaliauskas (2017). writes about a semi-structured interview, naming it as a flexible but vague survey because a survey is compiled for the survey, but there are no rigor requirements for the structure of the interview.

Bitine et al. (2008) emphasize that during the interview, the researcher may face some difficulties, such as deviating from the problem or topic under consideration. He also mentions that the researcher may have difficulty analyzing the answers when evaluating broad answers to questions.

Frechtling and Sharp (1997) argue that the choice of interviews as one of the methods of qualitative research is based on the assumption that one must know the views, experiences and opinions of the informant (s). 
INDEPENDENT JOURNAL OF MANAGEMENT \& PRODUCTION (IJM\&P)

http://www.ijmp.jor.br

v. 12, n. 6, Special Edition ISE, S\&P - November 2021

ISSN: 2236-269X

DOI: $10.14807 /$ ijmp.v12i6.1780

Informants (experts) were introduced to the purpose of the study. Individual time was allocated and coordinated with informant-experts at a time convenient for them.

According to Seitz (2016), modern communication technologies, as computer programs with a video call function, offer many interesting possibilities for researchers conducting qualitative research in an interview method. The interview was conducted remotely via a telecommunication video call "Facebook - messenger", the conversation was recorded by phone and lasted on average 45-60 minutes, followed by transcription.

Transcription data were systematically, consistently translated into text format, and line numbering was provided. Informants-experts were coded and named as EXPERT-1 (E1) and EXPERT-2 (E2) (Gaižauskaitė \& Valavičienè, 2016). Verbal consents were obtained allowing the recording of the conversation and the use of the content for scientific purposes.

The main interview tool - questions. According to McCoy, the authors of Morgan (2020) developed a semi-structured questionnaire and selected research topic: social skills.

The interview consisted of 10 open-ended questions related to the integration of refugee children and youth into society and opportunities for the development of social skills through football.

According to the researcher's decision, the subjects participating in the research are selected using the targeted selection method.

This method is widely used by researchers in qualitative research to identify more informative cases related to a phenomenon of interest. Targeted sampling is most often based on sampling according to established criteria (Patton, 2014; Palinkas et al., 2015), (see Table 1).

Table 1: Characteristics and selection criteria for the expert

\begin{tabular}{|c|l|}
\hline No & \multicolumn{1}{|c|}{ Criterion } \\
\hline 1. & Work experience with children and youth: Working with refugee children and youth \\
\hline 2. & Residence: living in Lithuania for more than 5 years. \\
\hline 3. & Activities: Physical activities-football activities are carried out \\
\hline 4. & Social skills: Cooperation and communication with social partners \\
\hline 5. & Work competence and qualification: Work experience, internships in other countries \\
\hline 6. & Relationships with football: Football coach \\
\hline 7. & Other: - Age / Education / Marital status \\
\hline 8. & Coding \\
\hline
\end{tabular}

Table 1 shows that both study informants-experts meet the selection criteria and characteristics of the selection. One of the main and most important selection criteria was that in order to work with refugee children and youth, work competence should be commensurate with the physical activity being carried out. 
DOI: $10.14807 /$ ijmp.v12i6.1780

Data processing: The study used a semi-structured interview approach. The obtained interview data were transcribed into a presentation in Microsoft Word format and searched for meaningful words, which were later grouped by topic, subtopics. The text of the interviews was transcribed in the authentic language of the informants.

\section{RESULTS}

The practical implementation of a football program begins at certain stages (see Figure 4). The program must reflect the layout of the content that is dedicated to the activities. To make it happen, you need to use development and implement the idea.

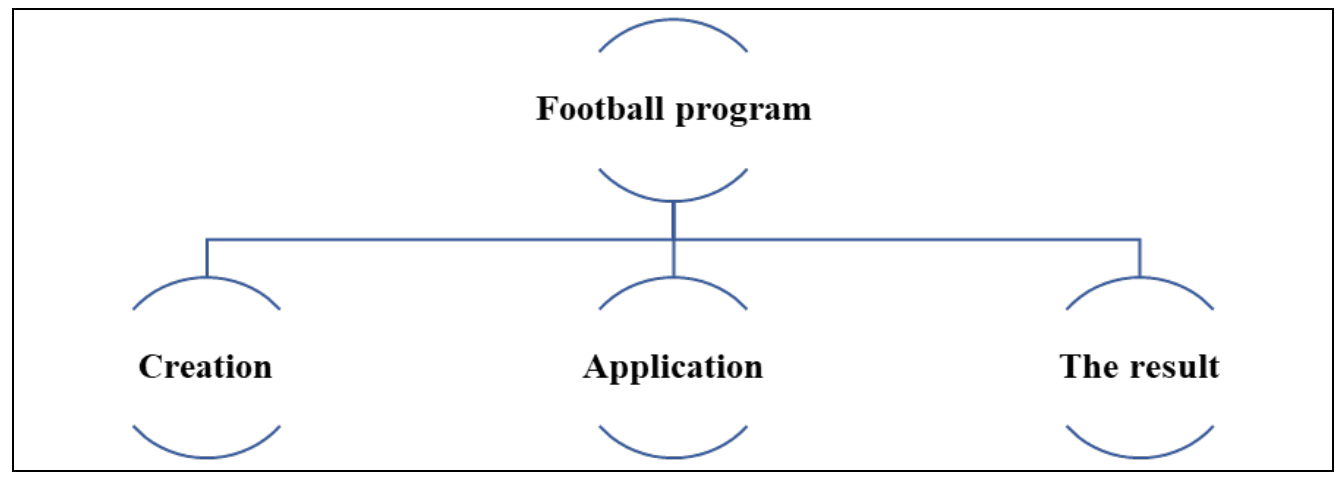

Figure 4: Stages of the practical evaluation of the football program

Analyzing the topic of the football program "Development", three sub-themes were identified: idea identification, writing, program adaptation (see Figure 5).

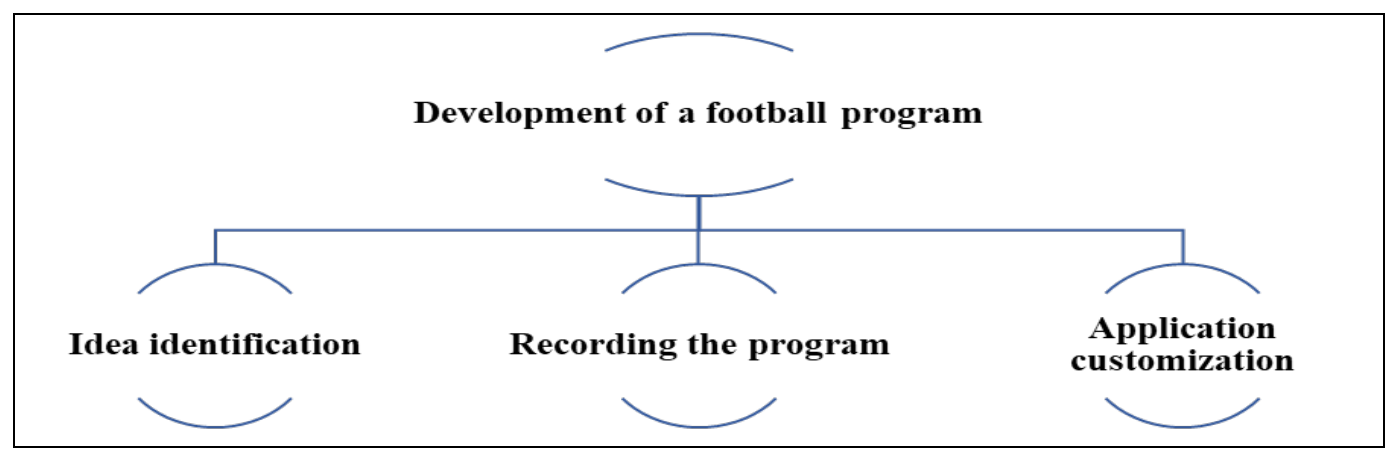

Figure 5: Subtopics of football program development

\section{- Sub-theme 1 - Idea identification}

The main step in solving the problem is an idea. The phenomenon of an idea is useful in achieving a goal. The research informant states that the implementation of the idea was determined by the Football3 approach, the experience of a coach, a social worker in France and as a volunteer football coach in India. During football activities, he noticed positive changes in the life of a child or young person. The observed changes were with social skills as lack of fear of language barrier, improved communication skills. We can be glad that the 
DOI: $10.14807 /$ ijmp.v12i6.1780

research participant, being of another nationality (French) living in Lithuania, developed and applied his idea to children and youth living in Lithuania.

\section{- Subtopic 2 - Program Capture}

The informant conveyed the practical idea in text format. As not only the head of the organization, the developer of the program, the football coach, but also the social worker, he set out the principles to be followed in the program. Football is used as a social tool, it implements the democratic idea that conditions are equal for all, and it also provides for and enabling action based on reflection. The program sets a goal, which reflects the otherness of this program, from other regular football programs, that the aim of this program is not sporting results, but a productive change in the life of a child or young person.

The content of the program is enriched by an annual plan, which includes: a training plan, a meeting with families, a variety of possible activities during the student holidays, contact with social partners, individual work and the organization of a summer camp. This program is inclusive in that there is a structure of activities formed by the football program, but also work with volunteers.

\section{- Sub-theme 3 - Application adaptation}

The program written by the research participant applies only to children and young people in the 7-19 age group. This football program is the only one in Lithuania and it applies to children and young people in the Vilnius city district, regardless of gender, nationality, quiet or loud, strong or weak.

Analyzing the theme of the football program “Application”, three sub-themes were identified: football activities, not focused on the sports result, development of communication skills (see Figure 6).

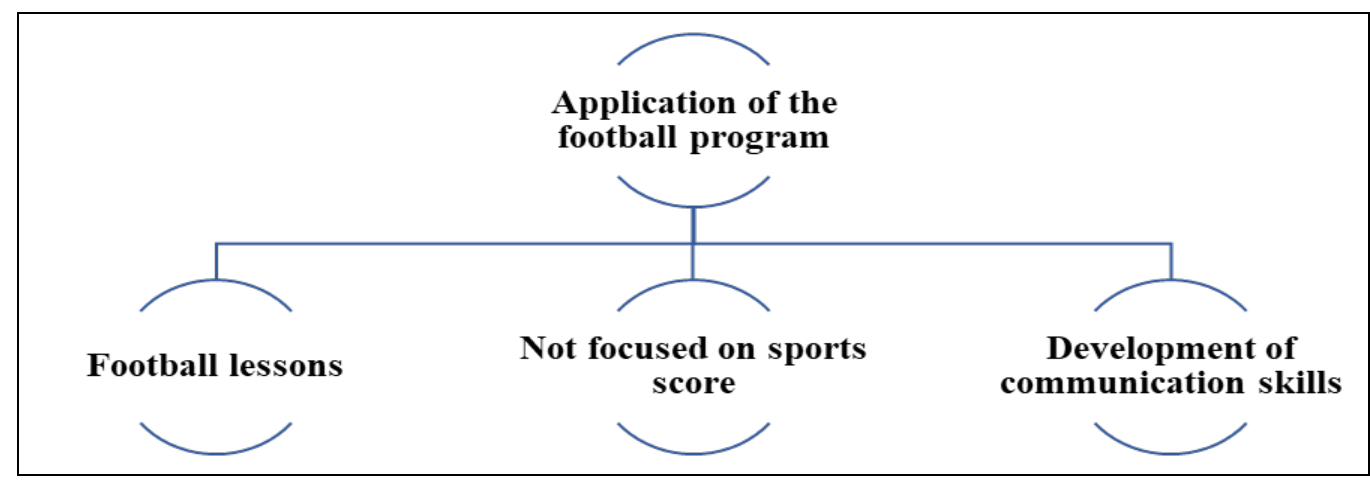

Figure 6: Subtopics of football program application

- Sub-theme 1 - Football activities

Informant E1 states that the program covers a period of 9 months. The football program consists of a structure that the coaches follow during the sessions. The research 
INDEPENDENT JOURNAL OF MANAGEMENT \& PRODUCTION (IJM\&P)

http://www.ijmp.jor.br

v. 12, n. 6, Special Edition ISE, S\&P - November 2021

ISSN: 2236-269X

DOI: $10.14807 /$ ijmp.v12i6.1780

informant follows the intended structure during E2 football sessions and lasts for about two hours. He also says that the quarantine has adjusted the sessions in a different direction.

\section{- Sub-theme 2 - Non-sports result oriented.}

The informants of the study, both E1 and E2, state that in Lithuania, sports are mainly focused on high mastery results and the aim is to earn money from circles. The football program created by the E1 informant is not aimed at a sporting outcome and is not a forprofit non-governmental organization. This program seeks qualitative benefits in the life of a child or young person.

\section{- Sub-theme 3 - Development of communication skills}

In this sub-theme, informant E2 points out that children and young people interact not only with their peers but also with adults during football activities. At the end of the sessions, they are encouraged to express their experience during the sessions - reflection. Informant E1 also says that he pays a lot of attention to the reflection of children and youth after football training.

Analyzing the theme of the football program "Outcome", three sub-themes were identified: development of social skills - opportunities, cooperation with social partners, stability of the program structure (see Figure 7).

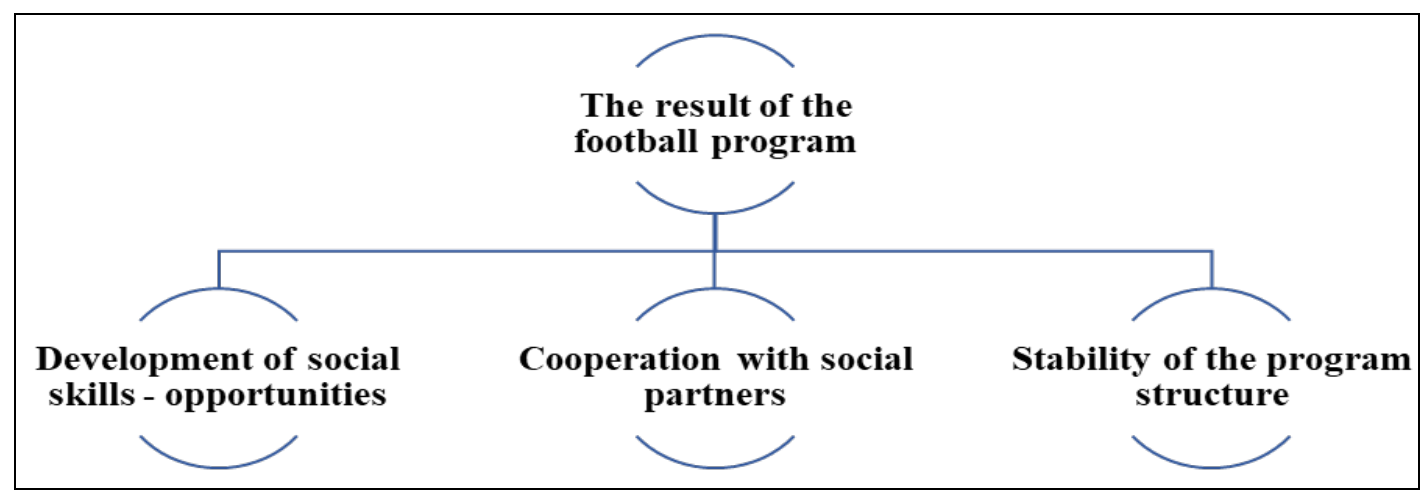

Figure 7: Sub-themes of the football program result

\section{- Sub-theme 1 - Development of social skills - opportunities}

Aldrige et al. (2018) argue that opportunities for social skills are acquired by interacting with the external environment that surrounds the individual directly. The research informant E2 identifies the development of social skills as football activities as a social work tool. Both informants E1 and E2 distinguish the following skills: “... independence ...”, “... leadership ...” “... listening to people ...”. "... building a relationship ...". "... perception of feelings ...". "... self-knowledge ...". "... self-control ...". "... overcoming stress ...". "...help...". "... the expression of feelings ...". 
INDEPENDENT JOURNAL OF MANAGEMENT \& PRODUCTION (IJM\&P)

http://www.ijmp.jor.br

v. 12, n. 6, Special Edition ISE, S\&P - November 2021

ISSN: 2236-269X

DOI: $10.14807 /$ ijmp.v12i6.1780

\section{- Sub-theme 2 - Cooperation with social partners}

Both study informants stressed that they are responsible for the results of their work with children and communicate with the social partners every year. Informant E1 states that she is looking for joint solutions with the social partners in the situation of a child or young person and, if necessary, the activities are carried out individually according to the need. Study informant E2 states that during the quarantine, children and young people worked individually according to the needs of their activities in an effort to maintain a good relationship with them.

\section{- Sub-theme 3 - Stability of the program structure}

Informant E1 could see the change or stability of the program structure when applying the football program in practice. Both informants in the study noted that the stability of the structure of the football program emerged in the third season.

The study revealed that the development of the football program and the effectiveness of practical efficiency were determined by the informant E1's experience abroad as a football coach, social worker and based on the applicability of the Football3 approach to the existing environment and audience. Informant E1, when creating the program, set the main important goal for the program that football results will not be achieved during football training, but will seek a qualitative change in the lives of children and young people.

This program does not aim to achieve high excellence in sporting outcomes, but is used as a social work tool to improve the personal and social skills of children and young people. This program consists of a target group of children and young people aged 7-19. Informants communicate and maintain close contact with the social partners, as well as with parents of children and young people. The duration of the football program is run in regular seasons i.e. 9 months a year.

The use of football as a tool for social work aims to improve the personal and social skills of children and young people. During physical activity, children and young people can develop different social skills such as coming to training on time, following the rules, being on the team, attending regular physical activities, learning to manage conflicts, feeling safe, communicating with peers and coaches, and learning to reflect on my football experience. workouts.

With the introduction of the football program in practice, it was possible to see the effectiveness of the practical result in the theoretical development of the program and its applicability in practice. Both football executives noticed that the stability of the program 
INDEPENDENT JOURNAL OF MANAGEMENT \& PRODUCTION (IJM\&P)

http://www.ijmp.jor.br

v. 12, n. 6, Special Edition ISE, S\&P - November 2021

ISSN: 2236-269X

DOI: $10.14807 /$ ijmp.v12i6.1780

structure emerged after the third season. This well-established program structure is implemented every year.

\section{CONCLUSIONS AND RECOMMENDATIONS}

a) Substantiation of the theoretical concept of physical activity of refugee children and youth. Man is a living, autonomous, intelligent, thinking being. Which may be young or old, a woman, a man or a child, hardworking or lazy, white or black, religious or nonreligious, educated or not, but he is still human. Various efforts to empower and protect consumers have been made by the government and various non-governmental consumer protection organizations.

b) The development of social skills and physical activity forms an autonomous personality by improving an individual's participation in society or a smaller community. Also, social skills are a fairly important part of an individual's construct that embraces the individual holistically in his or her social life

c) The Football3 football program, developed by the international network STREET FOOTBALL WORD, aims, on a practical basis, to be used by governmental or nongovernmental organizations around the world not only as a non-sporting sporting outcome, but also as a socio-educational support for children and young people. The aim of this tool / method is a productive qualitative change in the life of every child or young person. Using this method, it has become clear that football as a sport is a universal sports tool that changes the lives of refugee children and young people. The game of football gives refugee children and young people more self-confidence, develops and acquires new social skills, integrates more easily into host communities, schools, removes the barrier of bilingualism, the opportunity to communicate with peers and share reflection.

\section{REFERENCES}

Ali, M., Nugraha, H., \& Aqobah, Q. J. (2021). Traditional games and social skills of children in the pandemic era. JPsd (Jurnal Pendidikan Sekolah Dasar), 7(1), 104-117.

Alvesson, M. (2011). Interpreting interviews. Los Angeles: Sage Publications.

Anderson, A., Dixon, M. A., Oshiro, K. F., Wicker, P., Cunningham, G. B., \& Heere, B. (2019). Managerial perceptions of factors affecting the design and delivery of sport for health programs for refugee populations. Sport Management Review, 22(1), 80-95. DOI: 10.1016/j.smr.2018.06.015.

Anderson-Butcher, D., Martin, E., Paluta, L., \& Gould, D. (2018). Patterns of social skill development over - time among clusters of LiFE sports participants. Children and Youth Services Review, 87, 17-25. DOI: https://doi.org/10.1016/j.childyouth.2018.01.044. 
INDEPENDENT JOURNAL OF MANAGEMENT \& PRODUCTION (IJM\&P)

http://www.ijmp.jor.br

v. 12, n. 6, Special Edition ISE, S\&P - November 2021

ISSN: 2236-269X

DOI: $10.14807 /$ ijmp.v12i6.1780

Bandura, A. (2001). Social cognitive theory: An agentic perspective. Annual review of psychology, 52(1), 1-26. DOI: https://doi.org/10.1016/j.childyouth.2018.01.044.

Bartlett, L., Mendenhall, M., \& Ghaffar-Kucher, A. (2017). Culture in acculturation: Refugee youth's shooling experiences in international schools in New York City. International Journal of Intercultural Relations, 60, 109-119. DOI:

http://dx.doi.org/10.1016/j.ijintrel.2017.04.005

Berns, R. M. (2015). Child, family, school, community: Socialization and support. Cengage Learning.

Bitinas, B., Rupšienė, L., \& Žydžiūnaitè, V. (2008). Kokybinių tyrimų metodologija: vadovėlis vadybos ir administravimo studentams. Klaipėda: S. Jokužio leidykla-spaustuvè.

Bugental, D. B. (2000). Acquisition of the algorithms of social life: A domain-based approach. Psychological Bulletin, 126(2), 187-219. DOI: 10.1037/0033-2909.126.2.187.

Busch, J., \& Leyendecker, B. (2019). Socialization and Development of Refugee Children: Chances of Childcare. In Children's Social Worlds in Cultural Context (pp. 187-200). Springer, Cham. DOI: 10.1007/978-3-030-27033-9_14.

Butkus, M., \& Matuzevičiūtè, K. (2010). Migracijos tendencijų Europos sajungoje vertinimas. Ekonomika ir vadyba: aktualijos ir perspektyvos, 2, 28-38.

Castelli, F. (2018). Drivers of migration: why do people move? Journal of travel medicine, 25(1), 1-7, DOI: 10.1093/jtm/tay040.

Coakley, J. (2011). Youth sports: What counts as “positive development?”. Journal of sport and social issues, 35(3), 306-324. DOI: 10.1177\%2F0193723511417311.

Coalter, F. (2015). Sport-for-change: Some thoughts from a sceptic. Social Inclusion, 3(3), 19-23. DOI: 10.17645/si.v3i3.222.

Collins, W. A., Maccoby, E. E., Steinberg, L., Hetherington, E. M., \& Bornstein, M. H. (2000). Contemporary research on parenting: The case for nature and nurture. American Psychologist, 55(2), 218-232. DOI: 10.1037/0003-066X.55.2.218.

Cunningham, R., Bunde-Birouste, A., Rawstorne, P., \& Nathan, S. (2020). Young people’s perceptions of the influence of a sport-for-social-change program on their life trajectories. Social Inclusion, 8(3), 162-176. DOI: 10.17645/si.v8i3.2828.

Czosnek, L., Lederman, O., Cormie, P., Zopf, E., Stubbs, B., \& Rosenbaum, S. (2019). Health benefits, safety and cost of physical activity interventions for mental health conditions: A meta-review to inform translation efforts. Mental Health and Physical Activity, 16, 140-151.

Daniulienė, I., \& Dadelienė, R. (2020). Skirtingų fizinių veiklų poveikis pradinių klasių mokinių socializacijai. Sporto mokslas, 1, 83-83.

de Mooij, B., Fekkes, M., Scholte, R. H., \& Overbeek, G. (2020). Effective components of social skills training programs for children and adolescents in nonclinical samples: A multilevel meta-analysis. Clinical child and family psychology review, 1-15. DOI: 10.1007/s10567-019-00308-X.

Dewi, M. P., Neviyarni, S., \& Irdamurni, I. (2020). Perkembangan bahasa, emosi, dan sosial anak usia sekolah dasar. Jurnal Ilmiah Pendidikan Dasar, 7(1), 1-11. 
INDEPENDENT JOURNAL OF MANAGEMENT \& PRODUCTION (IJM\&P)

http://www.ijmp.jor.br

v. 12, n. 6, Special Edition ISE, S\&P - November 2021

ISSN: 2236-269X

DOI: $10.14807 /$ ijmp.v12i6.1780

Doidge, M., Keech, M., \& Sandri, E. (2020). 'Active integration': sport clubs taking an active role in the integration of refugees. International Journal of Sport Policy and

Politics, 12(2), 305-319. DOI: 10.1080/19406940.2020.1717580.

Ekholm, D. (2019). Sport as a means of governing social integration: Discourses on bridging and bonding social relations. Sociology of Sport Journal, 36(2), 152-161. DOI:

10.1123/ssj.2018-0099.

Flensner, K. K., Korp, P., \& Lindgren, E. C. (2021). Integration into and through sports?

Sport-activities for migrant children and youths. European Journal for Sport and

Society, 18(1), 64-81. DOI: 10.1080/16138171.2020.1823689.

Frechtling, J. A., \& Sharp, L. M. (Eds.). (1997). User-friendly handbook for mixed method evaluations. Diane Publishing.

Gadais, T., Ambrosini, B. F., \& Rioux, M. A. (2021). Proposal of milestones to map and understand the uses of sport for development and peace. DOI: 10.31236/osf.io/rjvcf

Gaižauskaitè, I., \& Valavičienė, N. (2016). Socialinių tyrimų metodai: kokybinis interviu. Vilnius: Registrų centras.

Giedrienè, R. (2015). Raidos sutrikimai ir vaiko socializacija. Vilnius: LEU leidykla

Gillham, J. E., Shatte, A. J., \& Freres, D. R. (2000). Preventing Depression:A Review of Cognitive -Behavioral and Family Intervations. Applied and Preventive Psychology, 9, 6388.

Harwood, G., Heesch, K. C., Sendall, M. C., \& Brough, M. (2021). The Basketball Boys: young men from refugee backgrounds and the symbolic value of swagger in an Australian state high school. International Journal of Inclusive Education, 1-16. DOI:

10.1080/13603116.2021.1941317.

Havighurst, S. S., Duncombe, M., Frankling, E., Holland, K., Kehoe, C., \& Stargatt, R. (2015). An emotionfocused early intervention for children with emerging conduct problems. Abnormal Child Psychology, 43(4), 49-60.

Im, H., Rodriguez, C., \& Grumbine, J. M. (2020). A multitier model of refugee mental health and psychosocial support in resettlement: Toward trauma-informed and culture-informed systems of care. Psychological Services. Advance online publication. DOI:

$10.1037 /$ ser0000412.

International Organization for Migration (2019). Integration migration law.Glossary on Migration. https://publications.iom.int/system/files/pdf/iml_34_glossary.pdf

Jasiulevičienė, R. (2008). Migracija žmogaus teisių diskurse. Oikos: lietuvių migracijos ir diasporos studijos. Vilnius: Versus Aureus, 1(5), 17-23.

Joo, C. H., \& Seo, D. I. (2016). Analysis of physical fitness and technical skills of youth soccer players according to playing position. Journal of exercise rehabilitation, 12(6), 548. DOI: $10.12965 /$ jer.1632730.365.

Kantas, I. (1980). Dorovès metafizikos pagrindai. Vilnius: Mintis.

Kardelis, K. (2016). Mokslinių tyrimų metodologija ir metodai:(edukologija ir kiti socialiniai mokslai): vadovèlis. Lietuvos kūno kultūros akademija. Šiauliai: Lucilijus.

Kay, T. (2012). Sport in the service of international development. Criminal Justice Matters, 88(1), 18-19. DOI: 10.1080/09627251.2012.695501. 
INDEPENDENT JOURNAL OF MANAGEMENT \& PRODUCTION (IJM\&P)

http://www.ijmp.jor.br

v. 12, n. 6, Special Edition ISE, S\&P - November 2021

ISSN: 2236-269X

DOI: $10.14807 /$ ijmp.v12i6.1780

Kvieskienè, G. (2003). Socializacija ir vaiko gerovè. Vilnius : Vilniaus pedagoginis universitetas.

Laumenskaite, I. E. (2014). Krikščioniškoji antropologija: problemos ir atvertys. SOTER: religijos mokslo žurnalas, 78(50), 95-114. DOI:10.7220/1392-7450.50(78).7.

Leveckytė, E., \& Junevičius, A. (2014). Lietuvos migracijos politika trečiųjų šalių piliečių atžvilgiu: patirtis ir tendencijos. Viešoji politika ir administravimas, 13(1), 149-162. DOI:10.5755/j01.ppaa.13.1.6758.

Litwiniuk, A., Waldzinski, T., \& Grants, J. (2020). Professional competences of personal trainers. Arch Budo Sci Martial Arts Extreme Sports, 16. Retrieved from http://smaes.archbudo.com/view/abstract/id/13967.

Luobikienė I. (2010). Socialinių tyrimų metodika. Kaunas: Technologija.

Maharmeh, Y. (2013). Street football at the Jordan refugee camp. Journal of Science and Medicine in Sport, 16, e83. DOI: 10.1016/j.jsams.2013.10.199

Mayar, F. (2013). Perkembangan sosial anak usia dini sebagai bibit untuk masa depan bangsa. Al-Ta lim Journal, 20(3), 459-464.

McCoy, S. M., \& Morgan, K. (2020). Obesity, physical activity, and sedentary behaviors in adolescents with autism spectrum disorder compared with typically developing

peers. Autism, 24(2), 387-399. DOI: 10.1177\%2F1362361319861579.

Michelini, E. (2021). Organised sport in refugee sites: An ethnographic research in Niamey. European Journal for Sport and Society, 1-17. DOI:

10.1080/16138171.2021.1878433.

Nassou, C., Skourti, C., Hopkins, P., Baker, C., Burton, L., Conibere, K., Levett, P., Morris, B., Sederberg, P., Aggerholm, J., Suhajda, V., Kolozsvajri, C., Schirosa, A., \& La Farina, G. (2020). Physical and Cultural Activity for Life Skills Development - Comparative Report. Project Report. University of Gloucestershire, Gloucester.

Opstoel, K., Chapelle, L., Prins, F. J., De Meester, A., Haerens, L., van Tartwijk, J., \& De Martelaer, K. (2020). Personal and social development in physical education and sports: A review study. European Physical Education Review, 26(4), 797-813. DOI: 10.1177\%2F1356336X19882054.

Orr, K., Wright, F. V., Grassmann, V., McPherson, A. C., Faulkner, G. E., \& ArbourNicitopoulos, K. P. (2021). Children and youth with impairments in social skills and cognition in out-of-school time inclusive physical activity programs: a scoping review. International Journal of Developmental Disabilities, 67(2), 79-93.

Palinkas, L. A., Horwitz, S. M., Green, C. A., Wisdom, J. P., Duan, N., \& Hoagwood, K. (2015). Purposeful sampling for qualitative data collection and analysis in mixed method implementation research. Administration and policy in mental health and mental health services research, 42(5), 533-544. DOI: 10.1007\%2Fs10488-013-0528-y.

Paradis, J., Chen, X., \& Ramos, H. (2020). The language, literacy, and social integration of refugee children and youth. Applied Psycholinguistics, 41(6), 1251-1254. DOI: 10.1017/S0142716420000788.

Paškevičè, A., \& Požėrienè, J. (2020). Neformalus vaikų ir jaunimo ugdymas pagal fizinę veiklą. Laisvalaikio tyrimai , 1 (15). DOI: 10.33607/elt.v1i15.920. 
INDEPENDENT JOURNAL OF MANAGEMENT \& PRODUCTION (IJM\&P)

http://www.ijmp.jor.br

v. 12, n. 6, Special Edition ISE, S\&P - November 2021

ISSN: 2236-269X

DOI: $10.14807 /$ ijmp.v12i6.1780

Pastoor, L. D. W. (2017). Reconceptualising refugee education: exploring the diverse learning contexts of unaccompanied young refugees upon resettlement. Intercultural Education, 28(2), 143-164. DOI: 10.1080/14675986.2017.1295572.

Patton, M. Q. (2014). Qualitative research \& evaluation methods: Integrating theory and practice. Sage publications.

Raffier, C. (2020). Vilniaus social club. Futbolo programa. Interviu. Vilnius.

Robinson, D. B., Robinson, I. M., Currie, V., \& Hall, N. (2019). The Syrian Canadian sports club: A community based participatory action research project with/for Syrian youth refugees. Social Sciences, 8(6), 163. DOI: 10.3390/socsci8060163.

Rupšienè, L. (2007). Kokybinio tyrimo duomenų rinkimo metodologija: Metodinė knyga. Klaipėda: Klaipėdos universiteto leidykla.

Seitz, S. (2016). Pixilated partnerships, overcoming obstacles in qualitative interviews via Skype: A research note. Qualitative Research, 16(2), 229-235. DOI:

$10.1177 \% 2 F 1468794115577011$.

Sibson, R., \& Stanway, A. R. (2020). Opening up perspectives on life: exploring the benefits of culturally and linguistically diverse (CaLD) sport and active recreation programs for participants. Managing Sport and Leisure, 1-20. DOI: 10.1080/23750472.2020.1787211.

Šidlauskienė, A., Strukčinskienė, B., Raistenskis, J., Stukas, R., Strukčinskaitė, V., \& Buckus, R. (2019). The association between the level of physical activity with spinal posture and physical fitness parameters in early adolescence. Vojnosanitetski pregled, 76(12), 1209-1216. DOI: https://doi.org/10.2298/VSP170517098S.

Simanjuntak, M., \& Mubarokah, U. (2020). Investigating how consumer education and lifestyle influence the consumer empowerment: case in rural and urban areas, Indonesia. Independent Journal of Management \& Production, 12(5), 1232-1249.

Simanjuntak, M., \& Umiyati, S. (2020). The effect of demographic, social, and economic characteristics on consumer empowerment in education institutions. Independent Journal of Management \& Production. Forthcoming, 12(5), 1282-1299.

DOI:10.14807/ijmp.v12i5.1443

Skirbutaitè, S. (2010). Pabėgėlių ir prieglobsčio prašytojų kultūrinès integracijos ypatumai: Suomijos ir Lietuvos lyginamoji analizè. Jaunųjų mokslininkų darbai, (1), 44-50.

Souza-Barba, L. (2012). Operant variability: A conceptual analysis. The Behavior Analyst, 35(2), 213-227. DOI: 10.1007/BF03392280.

Spence, S. H. (2003). Social skills training with children and young people: Theory, evidence and practice. Child and adolescent mental health, 8(2), 84-96. DOI: 10.1111/14753588.00051 .

Stančienè, D. M. (2002). Žmogus“، kaip dvasinè ir kūniška substancija, Tomo Akviniečio antropologijoje. Logotipai mokslo publikacijos, 28, 110-116.

Stone, C. (2018). Utopian community football? Sport, hope and belongingness in the lives of refugees and asylum seekers. Leisure Studies, 37(2), 171-183. DOI:

10.1080/02614367.2017.1329336.

Strazdienė, N., Strukčinskaitė, V., Strukčinskienė, B., Stukas, R., \& Arlauskas, R. (2020). Pradinių klasių mokinių fizinis aktyvumas ir sveikata: tėvų nuomonė. Visuomenès sveikata, 1(88), 86-91. 
INDEPENDENT JOURNAL OF MANAGEMENT \& PRODUCTION (IJM\&P)

http://www.ijmp.jor.br

v. 12, n. 6, Special Edition ISE, S\&P - November 2021

ISSN: 2236-269X

DOI: $10.14807 /$ ijmp.v12i6.1780

Street football world (2021). We want to change the world through football. Retrived from https://www.streetfootballworld.org/who-we-are/our-purpose Access: 24 June 2021.

Stura, C. (2019). What makes us strong: The role of sports clubs in facilitating integration of refugees. European Journal for Sport and Society, 16(2), 128-145.

Svensson, P. G., Woods, H. (2017). A systematic overview of sport for development and peace organizations. Journal of Sport for Development, 5(9), 36-48.

Šventas raštas. (2009). Lietuvos Vyskupų Konferencija. UAB: Katalikų pasaulio leidiniai. Vilnius.

Thomas, R. (2020). From social activism to active socialization: The evolution of football ideology in community-owned football clubs. Strategic Change, 29(4), 459-470. DOI: $10.1002 /$ jsc. 2357.

Tidikis R. (2003). Socialinių mokslų tyrimų metodologija. Vilnius: Lietuvos teisès universitetas.

Tuastad, D. (2014). From football riot to revolution. The political role of football in the Arab world. Soccer \& Society, 15(3), 376-388. DOI: 10.1080/14660970.2012.753541.

Ulme, G., Austers, I., Grants, J., \& Miķelsone, I. (2017). Motive Types Relations with Emotional Valence During Physical Activities. 3rd International Conference on Lifelong Education and Leadership for ALL. 999 - 1005.

United Nations High for Refugee Agency. (2019). Sport Programmes and Partnerships: International Olympic Committee. https://www.unhcr.org/uk/sport-partnerships.html

Vaitkevičius, J. (1995). Socialinès pedagogikos pagrindai.

Vazne, Z., Zidens, J., Grants, J., \& Svagzdiene, B. (2018). The Dependence of Latvian Handball Players' Effectiveness in Competitions on Psychological Indicators.

Transformations in Business \& Economics, 17(1), 100-111.

Vveinhardt, J., \& Ganusauskaite, A. (2021). Cross-cultural adaptation and reliability evaluation of the Lithuanian version of the key's questionnaire. Independent Journal of Management \& Production, 12(4), 1188-1202.

Weiss, M. R. (2011). Teach the children well: A holistic approach to developing psychosocial and behavioral competencies through physical education. Quest, 63(1), 55-65. DOI: 10.1080/00336297.2011.10483663.

Wright, P. M., Gordon, B., \& Gray, S. (2020). Social and emotional learning in the physical education curriculum. In Oxford Research Encyclopedia of Education. DOI: 10.1093/acrefore/9780190264093.013.1061.

Zaleckienė, R. (2004). Pilietinio ugdymo socialinė dimencija. Vilnius:LEU leidykla.

Žibas, K. (2017). Lietuvos visuomenès nuostatos prieglobsčio suteikimo ir pabėgèlių integracijos klausimais: apklausos rezultatai. Konferencijos medžiaga, LR seimas. 2017.10.09.

Žydžiūnaite, V., \& Sabaliauskas, S. (2017). Kokybiniai tyrimai: principai ir metodai: vadovèlis socialinių mokslų studijų programų studentams. Vilnius : Vaga. 